\title{
Oral Manifestations in Two Patients with a History of Asymptomatic COVID-19
}

\section{Thabet Maissa ${ }^{1 *}$, Kaltoum Mohamed ${ }^{2}$, Romdhane Wiem ${ }^{1}$, Fakhfakh Rym $^{1}$, Mzabi Anis ${ }^{1}$ and Laouani Chadia ${ }^{1}$}

${ }^{1}$ Internal Medicine Department, Sahloul Hospital, University of Sousse, Tunisia ${ }^{2}$ Mohamed Kaltoum Dental Clinic, Sousse, Tunisia

*Corresponding Author: Thabet Maissa, Internal Medicine Department, Sahloul Hospital, University of Sousse, Tunisia.
Received: November 08, 2020

Published: December 14, 2020

(C) All rights are reserved by Thabet Maissa., et al.

\begin{abstract}
The coronavirus disease 2019 (COVID-19) presents an important and urgent threat to global health. The lungs are the primary site of infection for COVID-19, with patients presenting symptoms ranging from mild flu-like symptoms to fulminant pneumonia and potentially lethal respiratory distress [1].
\end{abstract}

Keywords: COVID-19; Oral Manifestations; Headache

\section{Case 1}

A 30-year-old female patient, who works as a doctor in internal medicine department, manifests the presence of reddish lesion inside of the cheek of 3 days of evolution (Figure 1), two days after the patient presented a large ulceration of the tongue (Figure 2).

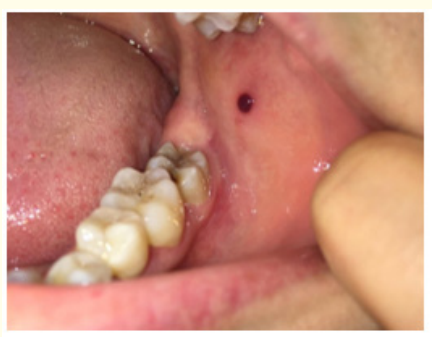

Figure 1: Reddish lesion inside of the cheek.

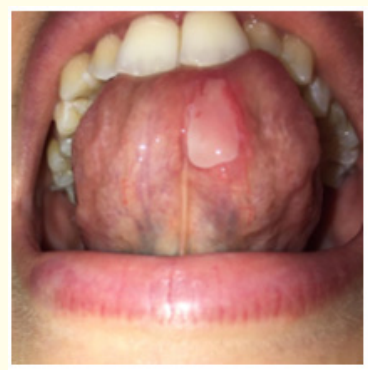

Figure 2: Large painful ulceration of the tongue.
During the anamnesis the patient indicated that she hadn't been taking medications and that she was in contact with covid-19 patients during her work. Few days after, she described the appearance of headache, hot flashes, anosmia and ageusia without fever or dyspnea.

The patient was tested positive for COVID-19 in Oral Swab Test and these oral manifestations disappeared within 10 days.

\section{Case 2}

A 60-year-old female patient manifests the presence of an ulceration of the upper lip (Figure 3), associated to an odynophagia. The oral examination revealed an erythematous angina (Figure 4). During the anamnesis the patient indicated that she hadn't been taking medications and that she was in contact with covid-19 patients within two weeks but she didn't have any COVID-19 symptom. The Oral Swab Test for COVID-19 was positive.

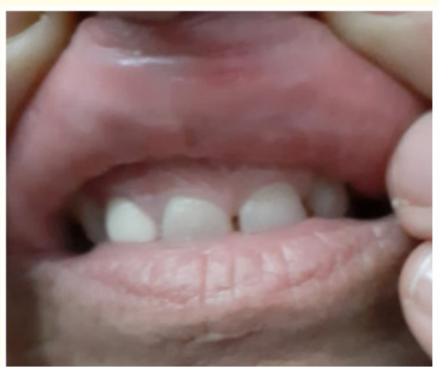

Figure 3: Ulceration of the upper lip in the process of healing. 


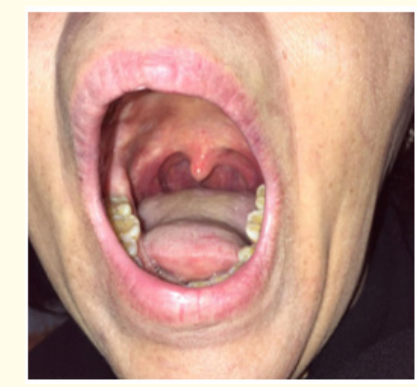

Figure 4: Erythematous angina.

\section{Discussion}

This is one of the first and rare reports of oral clinical manifestations of an asymptomatic patient with COVID-19.

Recent literature has reported few cases of oral manifestations of patients with COVID-19, but it is still doubt whether these are the result of direct action of the virus or a product of systemic deterioration that increases the probability of opportunistic injuries [2-5].

\section{Conclusion}

Therefore, the range of COVID-19 manifestations in the oral cavity has broad and current interest. This brief article's overall objective was to report two relevant cases of oral manifestations in a COVID-19 patient.

\section{Bibliography}

1. W Guan., et al. "Clinical characteristics of coronavirus disease 2019 in China". The New England Journal of Medicine 382 (2020): 1708-1720.

2. Ciccarese G., et al. "Oral erosions and petechiae during SARSCoV-2 infection". Journal of Medical Virology (2020).

3. Carreras-Presas CM., et al. "Oral vesiculobullous lesions associated with SARS-CoV-2 infection". Oral Disease (2020).

4. dos Santos JA., et al. "Oral mucosal lesions in a COVID-19 patient: new signs or secondary manifestations?" International Journal of Infectious Diseases 97 (2020): 326-328.

5. Corchuelo J and Ulloa FC. "Oral manifestations in a patient with a history of asymptomatic COVID-19: Case report". International Journal of Infectious Diseases 100 (2020): 154-157.

\section{Assets from publication with us}

- Prompt Acknowledgement after receiving the article

- Thorough Double blinded peer review

- Rapid Publication

- Issue of Publication Certificate

- High visibility of your Published work

Website: www.actascientific.com/

Submit Article: www.actascientific.com/submission.php

Email us: editor@actascientific.com

Contact us: +919182824667 